\title{
Association between Hemodialysis Adequacy, Family Support, and Quality of Life in Chronic Renal Failure Patients
}

\author{
Leo Chandra Wisnu Pandu Winata)2), Wachid Putranto3), Mohammad Fanani4) \\ ${ }^{1)}$ Kasih Ibu Hospital, Surakarta \\ ${ }^{2)}$ Masters Programs in Family Medicine, Sebelas Maret University \\ 3)Subdepartment of Renal Diseases, Department of Internal Medicine, \\ Dr. Moewardi Hospital, Surakarta \\ 4)Department of Psychiatry, Dr. Moewardi Hospital, Surakarta
}

\begin{abstract}
Background: Hemodialysis is one of renal replacement therapy for patients with chronic renal failure (CRF). The quality of hemodialysis is largely determined by the recommended dose of hemodialysis. Biological and psychological changes are often faced by patients undergoing hemodialysis, which can affect their quality of life. Family support is an important factor that serves as a support system for the patients to face the health problems. This study aimed to determine the association between hemodialysis adequacy, family support, and quality of life in chronic renal failure patients.

Subjects and Method: This was an analytic observational study with cross sectional design. It was conducted at Kasih Ibu Hospital, Surakarta, Central Java. A total sample of 102 patients with chronic renal failure who underwent hemodialysis were selected for this study using random sampling. The dependent variable was quality of life. The independent variables were hemodialysis adequacy and family support. The quality of life was assessed using the WHOQoL questionnaire. The hemodialysis adequacy was measured by Ureum Reduction Rate (URR) formula. Family support was measured by family support questionnaire. The data were analyzed using Chi Square test, Mann Whitney test, and logistic regression

Results: Patients with chronic renal failure had better quality of life if they underwent adequate hemodialysis $(\mathrm{OR}=5.34 ; 95 \% \mathrm{CI}=2.20$ to $12.98 ; \mathrm{p}=0.001)$ and received strong family support $(\mathrm{OR}=7.74 ; 95 \% \mathrm{CI}=3.13$ to $19.13 ; \mathrm{p}=0.001)$.

Conclusion: Quality of life of the patients with chronic renal failure is determined by hemodialysis adequacy and family support.
\end{abstract}

Keywords: chronic renal failure, hemodialysis, adequacy, family support, quality of life

Corespondence: Leo Chandra Wisnu Pandu Winata. Masters Programs in Family Medicine, Sebelas Maret University, Jl. Ir Sutami 36A, Surakarta. Email : leochandrawisnupw@gmail.com.

\section{BACKGROUND}

The incidence of global chronic renal failure is still towering. Based on National Institute of Diabetes, Digestive and Kidney Diseases, the number of chronic renal failure patients in USA by the end of 2009 was as many as 871,000 patients and only 570,000 people who underwent hemodialysis therapy or kidney transplantation. Meanwhile according to USDRS data, prevalence of chronic renal failure in USA in 2011 was 1,901 per million people (United State Renal Data System, 2013).

Based on the $7^{\text {th }}$ Report of Indonesian Renal Registry, the number of new chronic renal failure patients was 17.193 people (Perhimpunan Nefrologi Indonesia, 2014).

Hemodialysis is meant to restore body fluids and electrolytes back to their normal condition (Himmelfarb \& Ikizler, 2010). Based on Clinical Practice Guideline on Adequacy of hemodialysis, quality of hemodialysis is among others affected by hemo- 
dialysis adequacy, which is the recommended dosage to attain adequate result as the benefit of hemodialysis process undergone by renal failure patients (NKF-K/DOQI, 2006).

Some study results show that patients with chronic renal diseases who undergo hemodialysis possess worse quality of life compare to people in general (Bele et al 2012; Pakpour et al, 2010; Ayoub dan Hijjazi, 2013).

Septiwi (2010) in her study at Prof Dr Margono Soekarjo Hospital, Purwokerto states that there is a significant association between hemodialysis adequacy with the quality of life of hemodialysis patients $(\mathrm{OR}=8.98 ; 95 \% \mathrm{CI}=3.5$ to $23.08 ; \mathrm{p}$ $<0.001$ ). Pourfarziani et al. (2008) states that inadequacy of hemodialysis that can be evaluated from urea clearance which is not optimum leads to progressiveness of renal function impairment, thus increasing the level of morbidity and mortality of renal failure patients

Family support is an important factor when someone has to face (health) problems and also as a preventive strategy to reduce stress in which it broadens outlook on life, and helps controlling the emerging anxiety also depression (Ratna, 2010).

Saragih (2010) conveys the occurrence of significant association $(\mathrm{p}=0.001)$ between family support and the quality of life of hemodialysis patients. Istiqomah (2009) studied 35 hemodialysis patients who obtained family's attention, warmth, consolation, and help. They are likely to live passionately and improve their quality of life. The study showed significant association between social support with self acceptance and quality of life of hemodialysis patients. The higher the social support obtained by the patients, the more improvement of self acceptance and quality of life will be.

Based on the above descriptions the purpose of the study was to analyze the association of hemodialysis adequacy and family support with the quality of life of hemodialysis patients.

\section{SUBJECTS AND METHOD}

The study used analytic observational study with cross sectional approach. The study was conducted based on Ethical Clearance no. 177/III/HREC/2017. Population of study was 140 chronic renal failure patients who underwent regular hemodialysis in Kasih Ibu Hospital Surakarta in March 2017. The total sample of the study was 102 people that was taken by using systemic random sampling.

Independent variables of the study were hemodialysis adequacy and family support. Dependent variable was patients' quality of life. Hemodialysis adequacy was assessed from URR measuring by measuring the amount of urea reduction of hemodialysis patient from pre hemodialysis up to post hemodialysis

$\mathrm{URR}=100 \times 1(1-\mathrm{Ct} / \mathrm{Co})$

Information :

$\mathrm{Ct}$ : post HD urea

Co : pre HD urea

the result of calculation was then divided into 2 groups; good adequacy (URR $\geq 65 \%$ and less adequacy (URR < $65 \%)$.

Instrument of the study was in a form of WHOQoL-BREFF questionnaires to assess the quality of life of respondents. The World Health Organization Quality of Life-BREFF (WHOQOL-BREFF) was an improvement of WHOQOL - 100. The instrument consisted of 26 question items every item was equipped with 1-5 scale, which consisted of 4 domains. Out of 26 question items there were 2 general questions which were not included into 4 domain calculation, they were questions no 
1 and 2. There were 7 questions for health domain. There were 6 questions for psychology domain. There were 3 questions for social relationship domain. There were 8 questions for environment domain. Respondents were asked to select one figure out of 1-5 scale on each question. The quality of life was considered excellent if the total score $\geq 72$ and the quality of life was considered less if the total score $<72$ (WHO, 2004).

Family support questionnaires had passed validity and reliability test. It consisted of 12 question items with the score spanned from 1 up to 4 in which family support components consisted of instrumental dimension, informational dimension, emotional dimension, and appreciation dimension. The questionnairees were aimed to identify family support toward chronic renal failure patients who underwent hemodialysis therapy. The scores were categorized into:

$12-23=$ Insufficient family support

$24-35=$ Sufficient family support

$36-48=$ Excellent family support

Table 1. Respondents distribution based on sex categories, education, occupation, vascular access types, duration of hemodialysis, Hb level in Kasih Ibu Hospital Surakarta in March $2017(n=102)$.

\begin{tabular}{lcc}
\hline \multicolumn{1}{c}{ Variables } & Number & \% \\
\hline Sex Categories & & \\
Male & 68 & $66.7 \%$ \\
Female & 34 & $33.3 \%$ \\
Education & 81 & $79.4 \%$ \\
$\quad$ High Education & 21 & $20.6 \%$ \\
$\quad$ Low Education & & \\
Occupation & 52 & $51.0 \%$ \\
$\quad$ Employed & 50 & $49.0 \%$ \\
$\quad$ Unemployed & 7 & $6.9 \%$ \\
Hb level & 95 & $93.1 \%$ \\
$\quad$ Non Anemic & & \\
Anemic & 92 & $90.2 \%$ \\
Vascular Access Types & 10 & $9.8 \%$ \\
$\quad$ Av Shunt & & $82.4 \%$ \\
$\quad$ Non Av Shunt & 84 & $17.6 \%$ \\
Duration of Hemodialysis & 18 & \\
4.5 hours & & \\
4 hours & & \\
\hline
\end{tabular}

The data were collected by WHOQolBREFF. Bivariate and multivariate data analysis were used to observe the association among variables and evaluate the most significant effect of independent variables toward dependent variable. Statistic test used in bivariate analysis was Chi square Test with significance level about $95 \%$ and $\alpha$ was 0.05 in addition, in multivariate analysis it used logistic regression analysis test.

\begin{tabular}{l}
\hline RESULT \\
\hline The result of the study showed 50 \\
respondents (49\%) with good adequacy and \\
52 respondents $(51 \%)$ with less adequacy. \\
62 respondents $(59.8 \%)$ with excellent \\
family support, 30 respondents (30.4\%) \\
with sufficient family support and 10 res- \\
pondents (9,8\%) with poor family support. \\
64 respondents (63\%) had excellent quality \\
of life, and 38 respondents (37\%) had poor \\
quality of life.
\end{tabular}
quality of life. 
Further analysis on $5 \%$ alpha that there was a significant association between hemodialysis with quality of life ( $\mathrm{p}=0.001)$. The value of obtained OR was 5.34 which meant that respondents with good adequacy possessed the opportunity as much as 5.34 times to have excellent quality of life compared to respondents with less adequacy.

1. Bivariate Analysis

Table 2. Respondents distribution based on hemodialysis adequacy and quality of life in Kasih Ibu Hospital, Surakarta

\begin{tabular}{|c|c|c|c|c|c|c|}
\hline \multirow{2}{*}{ HD Adequacy } & \multicolumn{4}{|c|}{ Quality of life } & \multirow{3}{*}{$\mathbf{N}$} & \multirow{2}{*}{$\mathbf{p}$} \\
\hline & \multicolumn{2}{|c|}{ excellent } & \multicolumn{2}{|c|}{ poor } & & \\
\hline & $\mathrm{n}$ & $\%$ & $\mathrm{n}$ & $\%$ & & \\
\hline Adequate & 42 & 65.6 & 10 & 26.3 & 52 & 0.001 \\
\hline Inadequate & 22 & 34.4 & 28 & 73.7 & 50 & \\
\hline Total & 64 & 100 & 38 & 100 & 102 & \\
\hline
\end{tabular}

Table 3. Respondents distribution based on family support and quality of life in Kasih Ibu Hospital, Surakarta.

\begin{tabular}{lccccccc}
\hline \multirow{2}{*}{ Family Support } & \multicolumn{9}{c}{ Quality of Life } & \multirow{2}{*}{$\mathbf{N}$} & \multirow{2}{*}{ p } \\
\cline { 2 - 5 } & \multicolumn{2}{c}{ excellent } & \multicolumn{2}{c}{ poor } & & \\
\hline \multirow{2}{*}{ Excellent } & $\mathrm{n}$ & $\%$ & $\mathrm{n}$ & $\%$ & & \\
Insufficient & 50 & 78.1 & 12 & 31.6 & 62 & 0.001 \\
Poor & 13 & 20.3 & 17 & 44.7 & 30 & \\
Total & 1 & 1.6 & 9 & 23.7 & 10 & \\
\hline
\end{tabular}

Table 4. Respondents distribution based on vascular access types and duration of hemodialysis with hemodialysis adequcy in Kasih Ibu Hospital, Surakarta

\begin{tabular}{lcccccc}
\hline \multicolumn{1}{c}{ Variables } & \multicolumn{5}{c}{ Excellent } & \multicolumn{2}{c}{ Poor } & N & \multirow{2}{*}{ p } \\
\cline { 2 - 5 } & $\mathrm{n}$ & $\%$ & $\mathrm{n}$ & $\%$ & & \\
Vascular Access Types & & & & & & \\
AV Shunt & 46 & 88.5 & 46 & 92 & 92 & 0.55 \\
Non AV Shunt & 6 & 11.5 & 4 & 8 & 10 & \\
Total & 52 & 100 & 50 & 100 & 102 & \\
Duration of Hemodialysis & & & & & & \\
4-5 hours & 44 & 84.6 & 40 & 80 & 84 & 0.54 \\
4 hours & 8 & 15.4 & 10 & 20 & 18 & \\
Total & 52 & 100 & 50 & 100 & 102 & \\
\hline
\end{tabular}

Further analysis on 5\% alpha that there was no significant association between vascular acess types with hemodialysis adequacy $(\mathrm{p}=0.55)$. Further analysis on $5 \%$ alpha that there was no significant association between duration of hemodialysis with hemodialysis adequacy $(\mathrm{p}=0.54)$.

The analysis result of association between sex categories with quality of life 
obtained that $38(59.4 \%)$ male respondents possessed excellent quality of life, and 26 (40.6\%) female respondents possessed excellent quality of life. Further analysis on $5 \%$ alpha that there was a significant association between sex categories with quality of life $(\mathrm{p}=0.04)$. The obtained OR value was 0.39 which meant that male respondents possessed the opportunity as much as 0.39 times to have excellent quality of life compared to female respondents.

Table 5. Respondents distribution based on education, occupation, and level of hemoglobin with quality of life in Kasih Ibu Hospital, Surakarta

\begin{tabular}{|c|c|c|c|c|c|c|}
\hline \multirow{2}{*}{ Variables } & \multicolumn{4}{|c|}{ Quality of Life } & \multirow{2}{*}{$\mathbf{N}$} & \multirow{2}{*}{$\mathbf{p}$} \\
\hline & \multicolumn{2}{|c|}{ Excellent } & \multicolumn{2}{|c|}{ Poor } & & \\
\hline \multicolumn{7}{|l|}{ Sex Categories } \\
\hline Male & 38 & 59.4 & 30 & 78.9 & 68 & 0.040 \\
\hline Female & 26 & 40.6 & 8 & 21.1 & 34 & \\
\hline Total & 64 & 100 & 38 & 100 & 102 & \\
\hline \multicolumn{7}{|l|}{ Education } \\
\hline High & 52 & 81.2 & 29 & 76.3 & 81 & 0.550 \\
\hline Low & 12 & 18.8 & 9 & 23.7 & 21 & \\
\hline Total & 64 & 100 & 38 & 100 & 102 & \\
\hline \multicolumn{7}{|l|}{ Occupation } \\
\hline Employed & 33 & 51.6 & 19 & 50.0 & 52 & 0.880 \\
\hline Unemployed & 31 & 48.4 & 19 & 50.0 & 50 & \\
\hline Total & 64 & 100 & 38 & 100 & 102 & \\
\hline \multicolumn{7}{|l|}{ Hb level } \\
\hline Non Anemic & 4 & 6.2 & 3 & $7 \cdot 9$ & 7 & 0.750 \\
\hline Anemic & 60 & 93.8 & 35 & 92.1 & 95 & \\
\hline Total & 64 & 100 & 38 & 100 & 102 & \\
\hline
\end{tabular}

The analysis result of association between education level with quality of life obtained that $52(81.2 \%)$ respondents with high education possessed excellent quality of life, and 12 (18.8\%) respondents with low education level possessed quality of life. Further analysis on $5 \%$ alpha that there was no significant association between level of education with quality of life $(\mathrm{p}=0.55)$.

The analysis result of association between occupation with quality of life obtained that 33 (51.6\%) employed respondent possessed excellent quality of life, and 31 (48.4\%) unemployed respondents possessed excellent quality of life. Further analysis on 5\% alpha that there was no significant association between occupation and quality of life $(\mathrm{p}=\mathrm{o.880})$.

The analysis result of association between $\mathrm{Hb}$ level with quality of life obtained that $4(6.2 \%)$ non anemic respondents possessed excellent quality of life, and 60 (93.8\%) anemic respondents possessed excellent quality of life. Further analysis on $5 \%$ alpha that there was no significant association between $\mathrm{Hb}$ level and quality of life $(\mathrm{p}=0.750)$.

The analysis result on $5 \%$ alpha that there was a significant association between $\mathrm{Qb}$ with hemodialysis adequacy $(\mathrm{p}=0.001)$.

Table 6. Analysis result of $\mathrm{Hb}$ level based on hemodialysis adequacy in Kasih Ibu Hospital, Surakarta

\begin{tabular}{lllll}
\hline \multicolumn{1}{c}{ Variable } & \multicolumn{1}{c}{ Hemodialysis Adequacy } & $\mathbf{N}$ & $\mathbf{p}$ \\
\hline $\mathrm{Qb}$ & Adequate & 52 & 0.001 & \\
& Inadequate & 50 & & \\
\hline
\end{tabular}


Table 7. Analysis result on age and duration of hemodialysis based on quality of life in Kasih Ibu Hospital, Surakarta

\begin{tabular}{lllc}
\hline \multicolumn{1}{c}{ Variables } & \multicolumn{1}{c}{ Hemodialysis Adequacy } & N & p \\
\hline Age & Adequate & 64 & 0.98 \\
\multirow{2}{*}{ Duration of HD } & Inadequate & 38 & \\
& Adequate & 64 & 0.04 \\
& Inadequate & 38 & \\
\hline
\end{tabular}

There was no significant association between age and quality of life $(\mathrm{p}=0.980)$. There were a significant association between duration of hemodialysis with quality of life $(\mathrm{p}=0.040)$.

\section{Multivariate Analysis}

In this stage, a selection was conducted toward independent variables (hemodialysis adequacy and family support) and confounding variables (duration of hemodialysis, hemoglobin level, sex categories, age, education level, and occupation) that were associated with quality of life.

Based on the Table 8 hemodialysis adequacy, family support, and sex categories variables had $\mathrm{p}$ value $<0.05$ therefore they were included in multivariate modeling.

Table 8. Result of bivariate selection on logistic regression test of independent variables and confounding variables with quality of life

\begin{tabular}{lc}
\hline \multicolumn{1}{c}{ Variables } & p \\
\hline Hemodialysis Adequacy & 0.001 \\
Family Support & 0.001 \\
Hemoglobin Level & 0.751 \\
Sex Categories & 0.043 \\
Level of Education & 0.551 \\
Occupation & 0.879 \\
\hline
\end{tabular}

Table 9. Result of logistic regression analysis on hemodialysis adequacy, family support, and sex categories with the quality of life of chronic renal failure patients who underwent hemodialysis in Kasih Ibu Hospital, Surakarta

\begin{tabular}{lcc}
\hline \multicolumn{1}{c}{ Variables } & P & OR \\
\hline Hemodialysis Adequacy & 0.003 & 0.237 \\
Family Support & 0.040 & 2.709 \\
Sex Categories & 0.409 & 1.557 \\
\hline
\end{tabular}

The result of logistic regression test showed that out of 3 variables there were 2 variables with $\mathrm{p}$ value $>0.05$ and variable with the biggest $\mathrm{p}$ value was excluded (o.409) it was sex categories. The modeling analysis above showed that hemodialysis adequacy and family support variables had significant association with quality of life. Subsequently, the two variables would be tested in the next stage.

Table 10. Final result of multivariate analysis on hemodialysis adequacy and family support with quality of life of chronic renal failure patients who underwent hemodialysis in Kasih Ibu Hospital, Surakarta

\begin{tabular}{lcc}
\hline \multicolumn{1}{c}{ Variables } & p & OR \\
\hline Hemodialysis Adequacy & 0.001 & 0.21 \\
Family Support & 0.042 & 2.66 \\
\hline
\end{tabular}


Based on logistic regression analysis it could be concluded that respondents who attained hemodialysis adequacy had 0.2 times bigger possibility to have excellent quality of life compared to respondents who did not attain hemodialysis adequacy. And respondents with excellent family support had 2,6 times bigger possibility to have excellent quality of life compared to those who had insufficient family support. Family support possessed the biggest OR value therefore it could be concluded that family support was the variable with the biggest effect toward quality of life.

\section{DISCUSSION}

Accomplishment of hemodialysis process is determined by the fulfillment of hemodialysis dosage in accordance with patient's needs. Based on Clinical Practice Guideline on Adequacy of Hemodialysis, the sufficiency of hemodialysis dosage given is measured by using the term hemodialysis adequacy, which is the recommended dosage to get adequate result as the benefits of hemodialysis process undergone by renal failure patients (NKF- K/DOQI, 2000). K/ DOQI recommends that every session of hemodialysis administration is expected to be able to attain minimal adequacy with URR of $65 \%$. The result of the syudy on association between hemodialysis adequacy and family support with quality of life of chronic renal failure patients was out of 102 respondents, it obtained 52 respondents (51\%) who were able to attain minimal adequacy with URR of $65 \%$ as it is recommended by K/DOQI.

Based on chi square analysis on $5 \%$ alpha there was a significant association between hemodialysis adequacy with quality of life $(\mathrm{p}=0.001)$. The OR value of Chi Square analysis was 5.34 it meant that respondents attained excellent adequacy, had 5.34 times possibility to have excellent quality of life compared to respondents with inadequate adequacy ( $95 \% \mathrm{CI}=2.20$ to 12.98).

Pourfarziani et al (2008) states that inadequacy of hemodialysis that can be evaluated from urea clearance which is not optimum leads to progressiveness of renal function impairment, thus increasing the level of morbidity of renal failure patients. Whereas hemodialysis adequacy is indicated by patients who feel better and comfortable so that it will improve their quality of life

Quality of life is defined by Ferrans dan powers (1993) as a welfare condition which is experienced by someone and it comes from contentment/discontentment toward the important parts of their life. Subjective perception about contentment toward various aspects of life is considered as the primary determinant in the evaluation of quality of life, since contentment is a cognitive experience that represents evaluation toward condition of life which is stable in a long period of time.

An adequate hemodialysis process will give positive impact toward quality of life improvement. It is in accordance with a study by Cleary dan Drennan (2005) that also studied 97 hemodialysis patients in Ireland and the result states that patients with inadequate hemodialysis have less quality of life compare to patients with adequate hemodialysis. Rambod dan Rafii (2010) studied the association between hemodialysis adequacy with quality of life of hemodialysis patients in Iran, and the result shows the is a significant association between both variables with $\mathrm{p}$ value $=0.00$. Septiwi (2011) also studied 101 hemodialysis patients in di Prof. Dr. Margono Soekarjo Hospital Purwokerto and the result is there is an association between hemodialysis adequacy and patients' quality of life. 
The result of the study showed that there were more respondents (62 responden (59.8\%)) obtained excellent family support, compared to those who obtained insufficient family support (10 respondents (9.8\%)) .

Family is the smallest social unit which is the most closely connected to patients. Family becomes an important element in someone's life since it is a system in which there are family members who are interconnected and interdependent in giving support, love, security, and attention also play each respective role in harmony to attain mutual objectives (Friedman et al., 2014)

The result of analysis on association between family support and quality of life obtained that as many as $50 \quad(78.1 \%)$ respondents who had excellent family support possessed excellent quality of life. Chi square analysis on $5 \%$ alpha showed that there was a significant association between family support with quality of life $(p=0.001, \alpha=0.05)$. The value of obtained OR was 7.74. it meant that respondents who had excellent family support had 7.74 times possibility to have excellent quality of life compared to respondents with poor family support ( $95 \% \mathrm{CI}=3.13$ to 19.13 ).

The result of the study is in accordance with Saragih (2010) who conveys the occurrence of significant association $(p=0.001)$ between family support with quality of life of hemodialysis patients. Istiqomah (2009) also studied 35 hemodialysis patients in Surabaya, and the result shows the occurrence of significant association between social support with self acceptance and quality of life of hemodialysis patients $(\mathrm{p}=0.000)$.

Chronic renal failure patients who undergo hemodialysis may experience changes both biological and psychological. The psychological changes among others are insomnia, feel anxious and worry over their disease, boredom over continuously repeated hemodialysis and long duration of each administration of hemodialysis that takes 4-5 hours. Patients also suffer from anxiety, helplessness, despair, boredom, and low self esteem as well as body image disorder (Black dan Hawks, 2005), therefore family support here plays important role. Iskandar (2008) states that the support perceived can predict the effectiveness of coping, self adjustment, as well as physical and psychological welfare of someone. It happens because on individuals who feel that the support they need is provided, it is more potential to not experience excessive stress and they are more motivated to maintain their degree of health.

Griffin et al. (2001), in a longitudinal study conducted an investigation on the role of family toward health status of patients with chronic diseases. They find a strong relationship between the role of family with health status, in which negative support will lead to low health status of the patients.

Limitations of the study were random sampling that did not consider hemodialysis frequency yet neither observed patients' body weight that would determine the amount of rotation (Quick of blood) which possibly affected the attainment of hemodialysis adequacy. Researcher also only observed that all respondents used high flux dialyzer without distinguishing between new dialyzer and reused dialyzer dialiser high flux tanpa membedakan. Researcher ignored how many times reused dialyzer had been used during the study.

Based on the result of the study, researcher has made conclusions as follow:

1. There is a significant association between hemodialysis adequacy with quality of life of chronic renal failure patients who undergo regular hemo- 
dialysis.

2. There is a significant association between family support with quality of life of chronic renal failure patients who undergo regular hemodialysis.

3. There is a significant association between hemodialysis adequacy and family support with quality of life of chronic renal failure patients who undergo regular hemodialysis.

\section{REFERENCE}

$\overline{\text { Ayoub AM, Hijjazil KH (2013). Quality Of }}$ Life In Dialysis Patients From The United Arab Emirates. Journal of Family and Community Medicine.

Bele S, Bodhare T, Mudgalkar N, Saraf A, Valsangkar S (2012). Health Related Quality Of Life And Existential Concern Among Patients With End Stage Renal Disease. Indian Journal of Palliative Care.

Black JM, Hawks JH (2005). Medical Surgical Nursing Clinical Management For Positive Outcome 7 Edition. Philadheiphia; W.B Saunders Company.

Cleary J, Drennan J (2005). Quality of life of patients on hemodialysis for endstage renal disease. Journal of Advanced Nursing.

Ferrans C, Powers M (1993). Quality of life of Hemodialysis Patients, Anna Journal, 20 (5), 575-581.

Friedman M, Bowden, Jones EG (2014). Family Nursing: Research, Theory \& Practise. USA. Conecticut: Appleton and Lange.

Griffin KW, Friend R, Kaell A T, Bennet R. $S$ (2001). Distress Disease Status among Patients with Rhematoid Arthritis: Role of Coping Styles and Perceived Responses from Support Providers. Annals of Behavioral Medi- cine, 23. Diakses pada tanggal $5 \mathrm{Ma}-$ ret 2017 dari http://www.annals. org.

Himmelfarb J, Ikizler TA (2010). Medical Progress Hemodialysis. Engl J Med.

Iskandar $\mathrm{T}$ (2008). Studi Fenomenologi Stres dan Dukungan Sosial yang Dipersepsi oleh Pasien HIV/AIDS. Tesis. Fakultas Psikologi UI.

Istiqomah N (2009). Hubungan antara Dukungan dan Penerimaan pada Pasien Hemodialisis di Surabaya.

NIDDK (2012). Kidney Disease Statistics for the United States. U.S Departmentof Health And Human Services. USA.

NKF-K/DOQI (2006). Clinical Practice Guidelines and Recommendations. National Kidney Foundation. New York.

Pakpour AH, Saffari M, Yekaninnejad MS, Panahi D, Harrison AP (2010). Health Related Quality Of Life In A Sample Of Iranian Patients On Hemodialysis. International Journal Kidney Disease.

Perhimpunan Nefrologi Indonesia. 2014. $7^{\text {th }}$ Report of Indonesian Renal Registry. Jakarta.

Pourfarziani V, Ghanbarpour F, Nemati E, S, Einollahi B (2008). Laboratory Variables and Treatment Adequacy in Hemodialysis Patient in Iran. Journal of Nursing Scolarship.

Rambod M, Rafii F (2010). Perceived Social Support And Quality Of Life In Iranian Hemodialysis Patients. Journal Of Nursing Scholarship 42 (3): 242-249.

Ratna W (2010). Sosiologi dan Antropologi Kesehatan. Yogyakarta: Pustaka Rihamma.

Saragih DA (2010). Hubungan Dukungan Keluarga dengan Kualitas Hidup Pasien Gagal Ginjal Kronis yang Menjalani Terapi Hemodialisis di RSUP 
Indonesian Journal of Medicine (2017), 2(1): 63-72

https://doi.org/10.26911/theijmed.2017.02.01.07

Haji Adam Malik Medan. USU. Medan.

Septiwi C (2010). Hubungan Antara Adekuasi Hemodialisis dengan Kualitas Hidup Pasien Hemodialisis di Unit Hemodialisis RS Prof Dr. Margono Soekarjo Purwokerto. Tesis. Universitas Indonesia. Jakarta.
United State Renal Data System (USRDS), 2013. Incident and Prevalent Count by Quarter. Available From: http:// www.usrds.org/qtr/default.

World Health Organization (2004). The World Health Organization; Quality Of Life. Diakses pada 2 Januari 2016 dari http//www.whoqol.breff.org. 